\title{
GMR
}

\section{Genetic diversity as tool to identify standard leaf nutrients in cassava genotypes}

\author{
JAD Giles ${ }^{1}$, WP Rodrigues ${ }^{2}$, G Oliosi ${ }^{1}$, FL Partelli ${ }^{1}$, HD Vieira ${ }^{2}$ and Vanderlei da Silva Santos ${ }^{3}$ \\ ${ }^{1}$ Centro Universitário Norte do Espírito Santo, Federal University of Espírito Santo, São \\ Mateus, ES, Brazil \\ ${ }^{2}$ Centro of Agricultural Sciences and Technologies, Universidade Estadual do Norte \\ Fluminense, Campos dos Goytacazes, RJ, Brazil \\ ${ }^{3}$ Embrapa Cassava and Fruticulture, Rua Embrapa, S / N, mailbox 007, neighbourhood \\ Chapadinha, CEP 44380-000, Cruz das Almas, BA, Brazil \\ Corresponding Author: FL Partelli \\ E-mail: partelli@yahoo.com.br
}

Genet. Mol. Res. 16 (4): gmr16039862

Received November 14, 2017

Accepted December 08, 2017

Published January 03, 2018

DOI http://dx.doi.org/10.4238/gmr16039862

Copyright $@ 2017$ The Authors. This is an open-access article distributed under the terms of the Creative Commons Attribution ShareAlike (CC BY-SA) 4.0 License.

\begin{abstract}
Among the factors affecting cassava yield, the leaf nutrients content has received little attention since cassava genotypes may grow well under inappropriate nutrient supply, however showing inadequate nutritional quality of tuberous roots. Considering this aspect, the genetic diversity should be explored in order to determine standard leaf nutrients in cassava genotypes. Thus, this study aimed at verifying leaf nutrient content (NC) as well as relationships among leaf nutrients (NR) in order to establish standard leaf nutrient level in twelve cassava genotypes. The experiment was performed during 2014/2015 crop seasons in northern region of Espírito Santo State, Brazil. A total of 24 samples were collected from each cassava genotype for quantification of

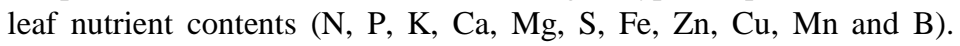
UPGMA method for quantifying genetic diversity as well as Scott-Knott for grouping averages were used. Our results reported low genetic diversity for both NC and NR, corroborating with grouping Scott-Knott test. Therefore, our leaf nutrients content values can represent an adequate nutritional status of cassava genotypes, which can be used as reference values for such specie
\end{abstract}


KEY WORDS: Manihot esculenta; Nutritional status;

Multivariate method; Leaf nutrients content

\section{INTRODUCTION}

Considering the current and future scenarios, crop science will face huge challenge. On one hand, it will be needed to increase crop yield, mainly those considered as primary foodstuffs for meeting the rising global food demand linked to population growth (Khoo and Knorr, 2014; Long et al., 2015; Ort et al., 2015). On the other hand, the impact of predicted climate changes on plant performance can cancel the possible future increases or even decrease currently crop yield (Pugh et al., 2016).

Among the primary foodstuffs, cassava (Manihot esculenta Crantz) is used by approximately one billion people in the daily diet, mainly in the tropical and subtropical regions of Asia, Latin America, and Africa (Brown et al., 2016). Additionally, this species is one of the important raw materials for starch preparation, which has several uses in the food, chemical, cosmetic, and pharmaceutical industries. According to FAO statistics (FAOSTAT, 2017), the cassava world production was > 268 million tons in 2016, being grown over an area of 23.87 million hectares, with an average yield of 11.24 tons per hectare.

Cassava is considered be a crop resistant to several biotic and abiotic stress, mainly drought and pests (Nhassico et al., 2008), although the predicted increases in air temperature and drought episodes can reduce tuber yield (Brown et al., 2016). Moreover, cassava plants can maintain its yield under inappropriate nutrient supply, in particular, at the expense of nutritional quality of tuberous roots (Pinstrup-Andersen, 2009). However, the increased availability of nutrients can increase tuberous roots yield (Alves et al., 2012). Therefore, researches focused on establishing adequate nutrient supply for cassava plants can maximize both tuber yield and quality.

Plant nutritional diagnosis depends on reference values such as critical level and sufficiency range for the nutrients concentration, especially in the leaves (Partelli et al., 2006; Gomes et al., 2016). However, these reference values are usually established in calibration experiments under controlled environments (Bhargava and Chadha, 1988), so that obtained values are of limited use. In addition, such values are continually revised because the introduction of new genotypes, improved methods of cultivation and environment changes, so requiring further experiments, which are often expensive and time-consuming, especially for perennial crops (Wadt et al., 1998). In this sense, a practical and efficient approach could be the use of nutrient status of leaves linked to the elevated productivity from several commercial crops to obtain reference values (Beaufils, 1973). However, such approach should consider the genetic diversity to establish a genotype-specific standard leaf nutrient.

Cassava is a diploid ( $2 n=36$ chromosomes) and monoic specie showing predominantly cross-pollination, thus, this specie is highly heterozygous (Pootakhan et al., 2014). Although cassava is vegetative propagated, such specie is considered to have large genetic diversity (Costa et al., 2013; Oliveira et Al., 2014; Silva et al., 2014). Therefore, the nutritional requirements can be different among cassava genotypes so that researches aiming at evaluating standard leaf nutrients are essential for establishing adequate nutrient supply for each genotype. Recent study done with coffee plants showed leaf nutrients diagnoses can be genotype-specific and depend on phenological stages (Gomes et al., 2016).

Considering other crops such as coffee, the leaf nutritional status can be interpreted using the "sufficiency range" method, which generates leaf nutrient contents that are used as a reference (Partelli et al., 2006), although it does not consider genetic diversity (Gomes et al., 2016). Regarding to this latter aspect, multivariate methods has been used as useful tool for quantifying genetic diversity (Carvalho et al., 2012, Guedes et al., 2013; Rodrigues et al., 2016; Kurosawa et al., 2017). Among multivariate methods, the unweighted pair group method with arithmetic mean (UPGMA) is considered more efficacious (Hale and Dougherty, 1988) and, therefore such method has been extensively used for quantifying genetic diversity in many species, including M. esculenta (Siqueira et al., 2009; Sanoussi et al., 2015). That said, the present study aimed at verifying the genetic diversity of leaf nutrients and establish the leaf nutrients content (NC) and their relationships (NR) of leaves from twelve cassava genotypes. We hypothesized that there is considerable genetic diversity which should be considered to establish a genotypespecific standard leaf nutrients. 


\section{MATERIAL AND METHODS}

Twelve cassava genotypes (Manihot esculenta Crantz; Table 1) were planted from 15-20 cm long cuttings and spaced $1 \times 0.6 \mathrm{~m}$. This experiment was performed during 2014/2015 crop seasons in Vila Valerio city, northern region of Espírito Santo State, Brazil (Latitude: $18^{\circ} 57^{\prime} 01^{\prime \prime} \mathrm{S}$; Longitude: $40^{\circ} 18^{\prime} 35^{\prime} \mathrm{W}$ ), at an altitude of 140 $\mathrm{m}$, with annual average temperature of $23{ }^{\circ} \mathrm{C}$. The climate is classified as Aw, e.g., a warm tropical climate with a dry season during winter and a rainy season during summer according to the Köppen classification (Köppen, 1931; Alvares et al., 2013), and average annual rainfall of $1200 \mathrm{~mm}$ (ANA, 2015).

\begin{tabular}{|c|c|c|}
\hline Code & Name & Provenience \\
\hline 1 & Gema de Ovo & Embrapa \\
\hline 2 & Eucalipto & Embrapa \\
\hline 3 & Camuquem & Embrapa \\
\hline 4 & Aipim do Sul & Embrapa \\
\hline 5 & Paraguai & Embrapa \\
\hline 6 & Cacauzinho & Embrapa \\
\hline 7 & Saracura & Embrapa \\
\hline 8 & São Rafael & Embrapa \\
\hline 9 & Cacau & Embrapa \\
\hline 10 & Amarela & Farmer* \\
\hline 11 & Goiás & Farmer* \\
\hline 12 & Mandioca Grande & Farmer* \\
\hline
\end{tabular}

At the time of planting, the soil was initially prepared using a disk harrow (grid) and rotary hoe. Thereafter, longitudinal furrows were made where the long cuttings were placed with $10 \mathrm{~cm}$ deep and subsequently covered. The both soil $\mathrm{pH}$ and fertility were adequately corrected based on soil analysis according to specific literature (Prezzoti et al., 2007; Partelli et al., 2010). P and K were applied as superphosphate (330 Kg ha $\left.{ }^{-1}\right)$ and potassium chloride $\left(100 \mathrm{Kg} \mathrm{ha}^{-1}\right)$, respectively, before planting, while top-dressing fertilization of $\mathrm{N}$ was carried out 50 days after planting as urea $\left(65 \mathrm{~kg} \mathrm{ha}^{-1}\right)$. During crop cultivation, especially in the initial phase, both sprinkle irrigation and manual weed control management strategies were adopted.

Leaf samples were collected six months after planting from twelve cassava genotypes. A composite sample of 24 leaves was collected during each evaluation period per genotype was placed in a paper bag and transported to the laboratory to determine the leaf $\mathrm{N}, \mathrm{P}, \mathrm{K}, \mathrm{Ca}, \mathrm{Mg}, \mathrm{S}, \mathrm{Fe}, \mathrm{Zn}, \mathrm{Cu}$, and $\mathrm{Mn}$ nutrient contents according to the method described by Silva (2009). We subsequently constructed a database to obtain the mean values for each genotype as well as the direct relationships among all the nutrients studied.

The data were analyzed simultaneously using the unweighted pair group method with arithmetic mean (UPGMA) method to create groups through clustering. For the UPGMA clustering method, the distance matrix was constructed by Mahalanobis's algorithm (Mahalanobis, 1936) using the Genes statistical software (Cruz, 2013). The distance matrix was used as a dissimilarity measure for the clustering analysis of the genotypes by the UPGMA method (dendrogram) using the statistical R software. To validate the clustering analysis, or to check the dendrogram's ability to play the dissimilarity matrices $\left(\mathrm{D}\right.$ and $\mathrm{D}^{2}$ ), we calculated the cophenetic correlation coefficient (CCC). The CCC is the Pearson correlation coefficient between the matrices of distance $\left(D^{2}\right.$ and $\left.D^{2}\right)$ and cophenetic matrix (C) (matrix of distances between genotypes, obtained from the dendrogram), and values close to unity indicate better representation (Cruz et al., 2014). Mean values of leaf nutrients content (NC) and direct relationships among nutrients (NR) data were subjected to analysis of variance, and the means were grouped according to the Scott-Knott test at 5\% probability using the Genes software (Cruz, 2013).

\section{RESULTS AND DISCUSSION}

Two clusters were formed based on Mahalanobis distance $\left(\mathrm{D}^{2}\right)$ and the cut-off point of the dendrogram proposed by Mojena (1977). The genotype 8 formed the first cluster while the second cluster was formed by other 
genotypes. The association between the cophenetic matrix and the distance matrix $\left(\mathrm{D}^{2}\right)$ was confirmed using the Mantel test $(\mathrm{P}<0.01)$ with 1000 permutations, with the CCC being higher than $88 \%$. (Figure 1 ).

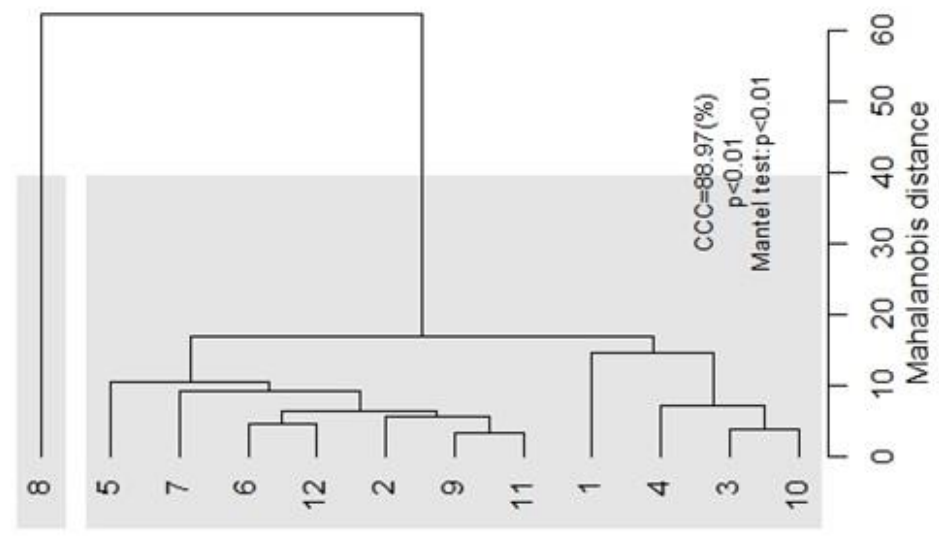

Figure 1. Dendrogram obtained by unweighted pair group method with arithmetic mean (UPGMA) based on Mahalanobis distance of twelve cassava genotypes with the cut-off point determined according to Mojena (1977) and cophenetic correlation coefficient (CCC).

Considering both $\mathrm{N}$ and $\mathrm{P}$, Scott-Knott test resulted in two groups, corroborating with clustering analysis of the genotypes by the UPGMA method, however, with difference in number of genotypes in each group (Table 2). Such discrepancy was also reported by Gomes et al. (2016) who assessed the genetic diversity of standard leaf nutrients in Coffea canephora genotypes during phenological phases. The genotypes 1, 3, 4 and 8 showed the higher $\mathrm{N}$ content values while the genotypes 1, 3, 4, 6 and 12 showed the higher $\mathrm{P}$ content ones. There were no significant differences among genotypes for other nutrients (Table 2).

\begin{tabular}{|c|c|c|c|c|c|c|}
\hline \multirow[t]{2}{*}{ Genotypes } & \multicolumn{6}{|c|}{ Nutrients } \\
\hline & $\mathrm{N}^{*}$ & $\mathrm{P}^{*}$ & $\mathrm{~K}^{\mathrm{ns}}$ & $\mathrm{Ca}^{\mathrm{ns}}$ & $\mathrm{Mg}^{\mathrm{ns}}$ & $\mathrm{S}^{\mathrm{ns}}$ \\
\hline 1 & $50.82 \mathrm{a}$ & $3.29 \mathrm{a}$ & 11.72 & 18.02 & 4.56 & 2.61 \\
\hline 2 & $43.73 \mathrm{~b}$ & $2.86 \mathrm{~b}$ & 11.25 & 18.36 & 3.41 & 2.38 \\
\hline 3 & $48.72 \mathrm{a}$ & $3.32 \mathrm{a}$ & 13.44 & 14.35 & 3.88 & 2.56 \\
\hline 4 & $47.29 \mathrm{a}$ & $3.32 \mathrm{a}$ & 14.38 & 17.33 & 3.84 & 2.39 \\
\hline 5 & $41.39 \mathrm{~b}$ & $2.55 \mathrm{~b}$ & 11.41 & 16.19 & 3.83 & 2.28 \\
\hline 6 & $43.24 \mathrm{~b}$ & $3.00 \mathrm{a}$ & 12.19 & 16.18 & 3.41 & 2.52 \\
\hline 7 & $43.28 \mathrm{~b}$ & $2.76 \mathrm{~b}$ & 12.35 & 19.91 & 4.07 & 2.49 \\
\hline 8 & $47.32 \mathrm{a}$ & $2.57 \mathrm{~b}$ & 12.19 & 19.22 & 3.41 & 2.73 \\
\hline 9 & $44.78 \mathrm{~b}$ & $2.63 \mathrm{~b}$ & 12.04 & 18.86 & 3.55 & 2.66 \\
\hline 10 & $45.68 \mathrm{~b}$ & $2.69 \mathrm{~b}$ & 12.50 & 19.26 & 3.69 & 2.61 \\
\hline 11 & $45.45 \mathrm{~b}$ & $2.81 \mathrm{~b}$ & 13.13 & 17.58 & 3.58 & 2.54 \\
\hline 12 & $44.78 \mathrm{~b}$ & $3.31 \mathrm{a}$ & 14.54 & 14.21 & 4.08 & 2.58 \\
\hline \multirow[t]{2}{*}{ Genotypes } & \multicolumn{6}{|c|}{ Nutrients } \\
\hline & $\mathrm{Fe}^{\mathrm{ns}}$ & $\mathrm{Zn}^{\mathrm{ns}}$ & $\mathrm{Cu}^{\mathrm{ns}}$ & $\mathrm{Mn}^{\mathrm{ns}}$ & $\mathrm{B}^{\mathrm{ns}}$ & \\
\hline 1 & 213.50 & 86.75 & 7.00 & 269.75 & 66.50 & - \\
\hline 2 & 150.75 & 70.00 & 6.50 & 200.00 & 67.75 & - \\
\hline 3 & 172.00 & 77.25 & 6.75 & 263.50 & 60.75 & - \\
\hline 4 & 159.50 & 76.00 & 6.25 & 231.00 & 59.50 & - \\
\hline 5 & 142.75 & $54.75 \mathrm{~b}$ & 5.25 & 222.25 & 72.25 & - \\
\hline 6 & 167.00 & 80.75 & 6.50 & 280.00 & 62.00 & - \\
\hline 7 & 152.00 & 72.25 & 5.25 & 258.75 & 61.50 & - \\
\hline 8 & 191.50 & 79.25 & 7.00 & 274.00 & 81.00 & - \\
\hline 9 & 193.25 & 79.50 & 6.75 & 305.50 & 78.50 & - \\
\hline 10 & 194.75 & 75.50 & 6.75 & 269.00 & 76.00 & - \\
\hline 11 & 173.25 & 72.00 & 6.25 & 256.75 & 68.75 & - \\
\hline 12 & 179.25 & 75.25 & 6.50 & 266.75 & 65.50 & - \\
\hline
\end{tabular}

For each nutrient, mean values followed by different letters indicate significant differences between genotypes according to the Scott-Knott test at $5 \%$ probability. NS $=$ not significant; *significant $(\mathrm{P} \leq 0.05)$.

The differences observed for both $\mathrm{N}$ and $\mathrm{P}$ may be linked to dynamic of such nutrients into plant metabolism, related to other factories such as growth and yield. For instance, $\mathrm{N}$ is a structural component of Ribulose-1,5bisphosphate carboxylase/oxygenase $(\mathrm{RuBisCO})$ and chlorophylls molecules which play a central role in photosynthetic activity (Lambers et al., 2008). P is essential for lipid membrane and ATP synthesis which is the energy currency for plant metabolism (Marschner, 1995; Taiz et al., 2015). Therefore, plants absorbing high levels 
of $\mathrm{N}$ and $\mathrm{P}$ may increase the cassava growth and yield (Séry et al., 2016). Despite differences among genotypes for such nutrients, the NC shown in table 2 could be used as reference values since the mean yield was ca. 30 tons $\mathrm{ha}^{-1}$, which is considered elevated compared to the mean national yields for Brazil (Devide et al., 2009).

Regarding the NR, significant differences were only observed in $\mathrm{P} / \mathrm{Zn}$ and $\mathrm{K} / \mathrm{Ca}$ relationships, where the genotypes $2,3,4,5,10,11$ e 12 showed the highest NR values for P/Zn, while the genotypes 3 and 10 showed the highest NR values for K/Ca (Table 3). The NR have been confirmed be useful in demonstrating the plant nutritional status since such method takes into account the relationships among nutrients rather than considering themselves in isolation (Partelli et al., 2006, 2007; Gomes et al., 2016). That said, our NR values can represent an adequate nutritional status of cassava genotypes, even though small differences were observed.

Table 3. Mean values and Scott-Knott test results for foliar nutrient relationships measured in twelve cassava genotypes during 2014/2015 crop seasons in Vila Valerio city, northern region of Espírito Santo State, Brazil.

\begin{tabular}{|c|c|c|c|c|c|c|c|c|}
\hline Genotypes & $\mathrm{N} / \mathrm{P}^{\mathrm{ns}}$ & $\mathrm{N} / \mathrm{K}^{\mathrm{ns}}$ & $\mathrm{N} / \mathrm{S}^{\mathrm{ns}}$ & $\mathrm{N} / \mathrm{Mg}^{\text {ns }}$ & $\mathrm{N} / \mathrm{Cu}^{\mathrm{ns}}$ & $\mathrm{N} / \mathrm{B}^{\mathrm{ns}}$ & $\mathrm{P} / \mathrm{Mg}^{\mathrm{ns}}$ & $\mathrm{P} / \mathrm{Zn}^{*}$ \\
\hline 1 & 15.48 & 4.44 & 19.51 & 11.28 & 7.35 & 0.76 & 0.73 & $0.038 \mathrm{~b}$ \\
\hline 2 & 15.30 & 4.02 & 18.49 & 12.82 & 6.85 & 0.65 & 0.84 & $0.043 \mathrm{a}$ \\
\hline 3 & 14.70 & 3.71 & 19.41 & 12.57 & 7.48 & 0.83 & 0.86 & $0.044 \mathrm{a}$ \\
\hline 4 & 14.47 & 3.31 & 20.34 & 12.69 & 7.89 & 0.84 & 0.87 & $0.045 \mathrm{a}$ \\
\hline 5 & 16.68 & 3.74 & 18.23 & 11.42 & 7.94 & 0.59 & 0.68 & $0.048 \mathrm{a}$ \\
\hline 6 & 14.44 & 3.73 & 17.23 & 12.76 & 6.82 & 0.70 & 0.88 & $0.039 \mathrm{~b}$ \\
\hline 7 & 15.75 & 3.56 & 17.41 & 10.90 & 8.46 & 0.71 & 0.70 & $0.038 \mathrm{~b}$ \\
\hline 8 & 18.53 & 3.90 & 17.37 & 14.37 & 7.05 & 0.58 & 0.78 & $0.032 \mathrm{~b}$ \\
\hline 9 & 15.94 & 3.49 & 17.68 & 12.71 & 7.29 & 0.65 & 0.80 & $0.040 \mathrm{~b}$ \\
\hline 10 & 13.84 & 3.18 & 17.75 & 11.92 & 7.16 & 0.71 & 0.86 & $0.044 \mathrm{a}$ \\
\hline 11 & 15.19 & 3.70 & 18.00 & 12.67 & 8.05 & 0.70 & 0.85 & $0.042 \mathrm{a}$ \\
\hline \multirow[t]{2}{*}{12} & 14.32 & 3.94 & 17.86 & 11.79 & 7.13 & 0.76 & 0.82 & $0.043 \mathrm{a}$ \\
\hline & \multicolumn{8}{|c|}{ Relationships } \\
\hline Genotypes & $\mathrm{P} / \mathrm{Cu}^{\text {ns }}$ & $\mathrm{K} / \mathrm{Ca}^{*}$ & $\mathrm{~K} / \mathrm{Mg}^{\text {ns }}$ & $\mathrm{K} / \mathrm{Mn}^{\mathrm{ns}}$ & $\mathrm{Ca} / \mathrm{Mg}^{\mathrm{ns}}$ & $\mathrm{Ca} / \mathrm{Mn}^{\mathrm{ns}}$ & $\mathrm{Fe} / \mathrm{Mn}^{\text {ns }}$ & \\
\hline 1 & 0.47 & $0.69 \mathrm{~b}$ & 2.65 & 0.047 & 3.93 & 0.068 & 0.83 & - \\
\hline 2 & 0.45 & $0.61 \mathrm{~b}$ & 3.33 & 0.064 & 5.40 & 0.100 & 0.84 & - \\
\hline 3 & 0.51 & $0.96 \mathrm{a}$ & 3.46 & 0.057 & 3.70 & 0.065 & 0.73 & - \\
\hline 4 & 0.55 & $0.84 \mathrm{~b}$ & 3.86 & 0.067 & 4.67 & 0.079 & 0.78 & - \\
\hline 5 & 0.48 & $0.70 \mathrm{~b}$ & 3.16 & 0.066 & 4.52 & 0.089 & 0.80 & - \\
\hline 6 & 0.47 & $0.77 \mathrm{~b}$ & 3.64 & 0.047 & 4.77 & 0.061 & 0.64 & - \\
\hline 7 & 0.53 & $0.62 \mathrm{~b}$ & 3.17 & 0.056 & 5.14 & 0.092 & 0.70 & - \\
\hline 8 & 0.38 & $0.64 \mathrm{~b}$ & 3.67 & 0.052 & 5.68 & 0.084 & 0.86 & - \\
\hline 9 & 0.46 & $0.75 \mathrm{~b}$ & 3.80 & 0.056 & 5.01 & 0.074 & 0.72 & - \\
\hline 10 & 0.52 & $1.12 \mathrm{a}$ & 3.78 & 0.058 & 3.47 & 0.055 & 0.73 & - \\
\hline 11 & 0.53 & $0.75 \mathrm{~b}$ & 3.41 & 0.045 & 4.84 & 0.063 & 0.62 & - \\
\hline 12 & 0.50 & $0.71 \mathrm{~b}$ & 2.99 & 0.051 & 4.24 & 0.076 & 0.84 & - \\
\hline
\end{tabular}

For each nutrient, mean values followed by different letters indicate significant differences between genotypes according to the Scott-Knott test at $5 \%$ probability. NS $=$ not significant; *significant $(\mathrm{P} \leq 0.05)$.

Considering our results together, the clustering analysis of the genotypes by the UPGMA method showed low genetic diversity among genotypes, corroborating with grouping Scott-Knott test. Therefore, our initial hypothesis was not sustained so that both NC and NR vales can be considered as adequate for demonstrating adequate nutritional status in a non-genotype-specific manner. Although we found low diversity genetic for NC and NR, the variability for other important traits such as growth and yield remain to be explored in such genotypes.

\section{CONCLUSION}

There was low genetic diversity among genotypes, so that clustering analysis of the genotypes by the UPGMA method resulted in two Clusters. The clustering analysis corroborated with grouping Scott-Knott test, which showed little differences among genotypes for both NC and NR. Finally, genetic diversity is a useful tool for establishing standard leaf nutrients content in cassava genotypes.

\section{CONFLICTS OF INTEREST}

The authors declare no conflict of interest.

\section{ACKNOWLEDGEMENTS}

The authors would like to thank the FAPES, CNPq, and CAPES for financial support. 


\section{REFERENCES}

Alvares CA, Stape JL, Sentelhas PC, Gonçalves JLM, et al. (2013). Köppen's climate classification map for Brazil. Meteorol. Z. 22: 711-728. https://doi.org/10.1127/0941-2948/2013/0507

Alves RNB, Modesto Júnior MS, Ferreira RE (2012). Doses de NPK na adubação de mandioca (Manihot esculenta) variedade Paulozinho em Moju -Pará. Rev. Raízes e Amidos Trop. 8: 65-70.

ANA, Agência Nacional de Águas (2015). A bacia do Rio Doce: características da bacia.

Beaufils ER (1973). Diagnosis and recommendation integrated system (DRIS). A general scheme of experimentation and calibration based on principles developed from research in plant nutrition. Soil Science Bulletin, 1. University of Natal, Pietermaritzburg, South Africa. 132. https://doi.org/10.17660/actahortic.1995.401.45

Bhargava BS, Chadha KL (1988). Leaf nutrient guide for fruit and plantation crops. Fert. News. 33: 21-29.

Brown AL, Cavagnaro TR, Gleadow R, Miller RE (2016). Interactive effects of temperature and drought on cassava growth and toxicity: implications for food security? Glob. Change Biol. 22: 3461-3473. https://doi.org/10.1111/gcb.13380

Carvalho AM, Mendes ANG, Botelho CE, Oliveira ACB, et al. (2012). Desempenho agronômico de cultivares de café resistentes à ferrugem no Estado de Minas Gerais, Brasil. Bragantia. 71: 481-487.

Costa TR, Vidigal Filho OS, Vidigal MCG, Galván MZ, et al. (2013). Genetic diversity and population structure of sweet cassava using simple sequence repeat (SSR) molecular markers. Afr. J. Biotechnol. 12: 1040-1048.

Cruz CD (2013). Programa Genes (Versão Windows): Aplicativos Computacionais em Genética e Estatística. Universidade Federal de Viçosa, Viçosa, Brazil.

Cruz CD, Carneiro PCS, Regazzi AJ (2014). Modelos Biométricos Aplicados ao Melhoramento Genético. Vol. 2. 3rd. Editora UFV, Viçosa, Brazil.

Devide ACP, Ribeiro RLD, Valle TL, Almeida DL, et al. (2009). Produtividade de raízes de mandioca consorciada com milho e caupi em sistema orgânico. Bragantia 68: 145-153. https://doi.org/10.1590/s0006-87052009000100016

FAOSTAT - FOOD AND AGRICULTURE ORGANIZATION OF THE UNITED NATIONS (2017).

http://faostat3.fao.org/download/Q/QC/E >. Accessed 15 March 2015.

Gomes WR, Rodrigues WP, Vieira HD, Oliveira MG, et al. (2016). Genetic diversity of standard leaf nutrients in Coffea canephora genotypes during phenological phases. Gen. Mol. Res. 15: gmr.15048839. https://doi.org/10.4238/gmr.15048839

Guedes J, Vilela DJM, Rezende JC, Silva FL (2013). Divergência genética entre cafeeiros do germoplasma Maragogipe. Bragantia 72: 127132. https://doi.org/10.1590/s0006-87052013000200003

Hale RL, Dougherty D (1998) Differences between Ward's and UPGMA methods of cluster analysis: implications for school psychology. J. School Psychol. 26: 121-131. https://doi.org/10.1016/0022-4405(88)90014-3

Khoo CS, Knorr D (2014). Grand challenges in nutrition and food science technology. Front. Plant Sci. 1:4. https://doi.org/10.3389/fnut.2014.00004

Köppen W (1931) Climatologia. México, Fundo de Cultura Econômica.

Kurosawa RNF, Amaral Junior AT, Silva FHL, Santos A, et al. (2016). Multivariate approach in popcorn genotypes using the Ward-MLM strategy: morphoagronomic analysis and incidence of Fusarium Spp. Gen. Mol. Res. 16: gmr16019528. https://doi.org/10.4238/gmr16019528

Lambers H, Chapin III FS, Pons JL (2008). Plant Physiological Ecology. 2nd Edition. Springer-Verlag, NY.

Long SP, Marshall-Colon A, Zhu X-G (2015). Meeting the global food demand of the future by engineering crop photosynthesis and yield potential. Cell. 161: 56-66. https://doi.org/10.1016/j.cell.2015.03.019

Marschner H (1995) Mineral Nutrition of Higher Plants. 2nd ed. Academic Press, London

Mohammadi SA, Prasanna BM (2003). Analysis of genetic diversity in crop plants-salient statistical tools and considerations. Crop Sci. 43: 1235-1248. https://doi.org/10.2135/cropsci2003.1235

Mojena R (1977). Hierarchical grouping method and stopping rules an evaluation. Comput. J. 20: 359-363.

Nhassico D, Muquingue H, Cliff J, Cumbana A, et al. (2008). Rising African cassava production, diseases due to high cyanide intake and control measures. J. Sci. Food Agric. 88: 2043-2049. https://doi.org/10.1002/jsfa.3337

Oliveira EJ, Ferreira CF, Santos VS, Jesus ON, et al. (2014) Potential of SNP markers for the characterization of Brazilian cassava germplasm. Theor. Appl. Genet. 127: 1423-1440. https://doi.org/10.1007/s00122-014-2309-8

Ort DR, Merchant SS, Alric J, Barkan A, et al. (2015) Redesigning photosynthesis to sustainably meet global food and bioenergy demand. Proc. Nat. Acad. Sci. USA. 112: 8529-8536. https://doi.org/10.1073/pnas.1424031112

Partelli FL, Vieira HD, Monnerat PH, Viana AP (2006). Estabelecimento de normas Dris em cafeeiro conilon orgânico ou convencional no estado do Espírito Santo. Rev. Bras. Cienc. Solo 30: 443-451.

Genetics and Molecular Research 16 (4): gmr16039862 
Partelli FL, Viera HD, Carvalho VB, Mourão Filho FAA (2007). Diagnosis and recommendation integrated system norms, sufficiency range, and nutritional evaluation of Arabian coffee in two sampling periods. J. Plant Nutr. 30: 1651-1667. https://doi.org/10.1080/01904160701615525

Partelli FL, Ramos JGA, Takeuchi KP, Vieira HD. (2010) Cultivo da mandioca no cerrado goiano.1ed. Vieira, GO.

Pinstrup-Andersen P (2009) Food security: definition and measurement. Food Sec. 1: 5-7.

Prezotti LC, Gomes JA, Dadalto GG, Oliveira JA (2007) Manual de recomendação de calagem e adubação para o Estado do Espírito Santo $5^{\mathrm{a}}$ aproximação. SEEA/Incaper/Cedagro, ES.

Pugh TAM, Muller C, Elliott J, Deryng D, et al. (2016). Climate analogues suggest limited potential for intensification of production on current croplands under climate change. Nat. Commun. 7: 12608. https://doi.org/10.1038/ncomms12608

Rodrigues WP, Vieira HD, Teodoro PE, Partelli FL, et al. (2016). Assessment of genetic divergence among coffee genotypes by Ward-MLM procedure in association with mixed models. Genet. Mol. Res. 15: 1-7. https://doi.org/10.4238/gmr.15027889

Sanoussi AF, Loko LY, Ahissou H, Adjahi AK, et al. (2015). Diversity, physicochemical and technological characterization of elite cassava (Manihot esculenta Crantz) cultivars of Bantè, a district of central Benin. Scient.World J. art ID 674201.

https://doi.org/10.1155/2015/674201

Séry DJ-M, Kouadjo ZGC, Voko BRR and Zézé A (2016). Selecting native arbuscular mycorrhizal fungi to promote cassava growth and increase yield under field conditions. Front. Mic. 7: 2063. https://doi.org/10.3389/fmicb.2016.02063

Silva FC (2009). Manual de análise química de solos, plantas e fertilizantes. 2nd ed. Embrapa, Brasília, DF

Silva AMO, Silva GF, Dias MC, Clement CR, et al. (2014). Inter-retrotransposon-amplified polymorphism markers for germplasm characterization in Manihot esculenta (Euphorbiaceae). Gen. Mol. Res. 13: 3800-3804. https://doi.org/10.4238/2014.may.16.3

Siqueira MVBM, Queiroz-Silva JR, Bressan EA, Borges A, et al. (2009). Genetic characterization of cassava (Manihot esculenta) landraces in Brazil assessed with simple sequence repeats. Gen. Mol. Biol. 32: 104-110. https://doi.org/10.1590/s1415-47572009005000010

Taiz L, Zeiger E, Møller IM, Murphy A (2015). Plant Physiology and Development, Sixth Edition. Sinauer Associates, Inc.

Wadt PGS, Novais RF, Alvarez VVH, Fonseca S, Barros NF (1998). Valores de referência para macronutrientes em eucalipto obtidos pelos métodos DRIS e chance matemática. R. Bras. Ci. Solo 22: 685-692. 